\title{
TEKNIK PENINGKATAN DAYA DAN KECEPATAN BERKECAMBAH BENIH PILANG
}

\author{
Techniques for Increasing Seed Viability of Acacia leucophloea (Roxb) Wild. \\ Eliya Suita dan/and Sofwan Bustomi ${ }^{2}$ \\ ${ }^{1}$ Balai Penelitian Teknologi Perbenihan Tanaman Hutan \\ Jl. Pakuan Ciheuleut Kotak Pos 105 Bogor, Telp./Faks. 0251-8327768 \\ Email : eliyasuita@yahoo.co.id \\ ${ }^{2)}$ Pusat Penelitian dan Pengembangan Peningkatan Produktivitas Hutan \\ Jl. Gunung Batu No. 5 Kotak Pos 331 Bogor \\ Telp. 0251-8631238, Faks. 0251-7520005
}

Naskah masuk : 30 Mei 2013 ; Naskah diterima : 21 Februari 2014

\begin{abstract}
Pilang (A. leucophloea) is a potential species for firewood and suitable for planting in stabilizing degraded land due to its compact root system. This research aims to find out the best method for seed germination to increase the seed viability. Test method includes pre-treatments: control, soaking the seed in coconut water for 30 and 60 minutes, in $\mathrm{H}_{2} \mathrm{SO}_{4}$ for 20 and 40 minutes, in boiled water $\left(100^{\circ} \mathrm{C}\right)$ and then put into cold water for 24 hours. The seeds, after pretreatments, were sowed by using methods: Top on Paper (TP), Between paper (BP), Rolled paper wrapped by plastic in standing position in the germinator, mixed media of sand and soil (1:1), mixed media of sand and soil $(1: 1)$ covered by plastic for 1 week. The best pre-treatment and germination method for pilang is soaking the seed in $\mathrm{H}_{2} \mathrm{SO}_{4}$ for 20 menit by using TP method.
\end{abstract}

Keywords: Acacia leucophloea, firewood, viability, test methods, orthodoxs seed

\begin{abstract}
ABSTRAK
Pilang (A. leucophloea) merupakan salah jenis potensial untuk kayu energi dan cocok ditanam pada lahan terdegradasi, karena mempunyai sistem perkaran yang kompak. Tujuan penelitian untuk mendapatkan metode uji perkecambahan yang dapat meningkatkan viabilitas benih. Metode uji meliputi pengujian perlakuan pendahuluan: kontrol (tanpa perlakuan), benih direndam dalam air kelapa selama 30 dan 60 menit, dengan $\mathrm{H}_{2} \mathrm{SO}_{4}$ selama 20 dan 40 menit, dalam air panas (suhu $100^{\circ} \mathrm{C}$ ) selama 10 dan 20 detik kemudian masukkan air ke dalam air biasa selama 24 jam. Setelah perlakuan pendahuluan benih di tabur dengan metode : UDK (Uji Di atas Kertas), UAK (Uji Antar Kertas), UKDdp (Uji Kertas Digulung dengan posisi didirikan), media pasir tanah (1:1), media pasir tanah (1:1) ditutup plastik selama 1 minggu pertama. Perlakuan pendahuluan dan metode uji perkecambahan terbaik adalah benih direndam dengan $\mathrm{H}_{2} \mathrm{SO}_{4}$ selama 20 menit dengan metode uji UDK.
\end{abstract}

Kata kunci: A. leucophloea, kayu energi, daya dan kecepatan berkecambah, metode uji, benih ortodoks

\section{PENDAHULUAN}

Kebutuhan energi dari tahun ke tahun terus meningkat seiring dengan bertambahnya penduduk dunia. Sehubungan dengan sumber energi dari sumberdaya alam yang tidak dapat diperbaharui atau bahan bakar fosil sangat terbatas dan cenderung semakin berkurang, maka perlu upaya mencari energi alternatif baik dari sumber daya alam lainnya maupun sumberdaya alam terba- harukan. Salah satu energi terbarukan diantaranya energi berbasis biomassa (energi biomassa).

Energi biomassa, khususnya kayu bakar masih merupakan sumber energi dominan (sekitar $80 \%$ ) bagi masyarakat pedesaan berpenghasilan rendah dengan tingkat konsumsi $1,2 \mathrm{~m}^{3} /$ orang/ tahun (Tampubolon, 2008).

Salah satu jenis tanaman yang potensial untuk kayu bakar adalah pilang (Acacia leucophloea (Roxb) Wild.). Jenis ini termasuk suku legumi- 
nosae yang memiliki nilai kalor tinggi sebesar $5.218 \mathrm{kal} /$ gram dengan produktivitas energy sebesar 258,3 GJ/ha/tahun (Bustomi, 2009). Pohon pilang, jenis cepat tumbuh, dapat tumbuh pada tanah kering, savanna dan lahan marginal (lahan kritis) dengan curah hujan rendah antara 400 $1.500 \mathrm{~mm}$ per tahun dan musim kemarau berlangsung 910 bulan. Penyebaran secara alaminya meliputi wilayah kering India, Srilangka, Bangladesh, Burma, Thailand, dan di Indonesia tumbuh alami di Jawa, Bali dan Timor (http://id.wikipedia.org/Pilang Pengenalan; NFTA Fact sheet, 2011).

Untuk mendukung keberhasilan penanaman pilang, maka penyediaan benih bermutu menjadi persyaratan yang diperlukan. Biji pilang termasuk benih yang tidak mudah berkecambah dalam waktu singkat. Benih dikatakan sulit berkecambah jika waktu yang diperlukan untuk berkecambah lebih dari seminggu dan daya berkecambah yang rendah. Hal ini telah dibuktikan hasil penelitian seleksi dan perendaman dengan air panas, persentase berkecambah benih pilang paling tinggi $27,2 \%$ (Suita, Ismiati, \& Putra, 2010) dan menurut hasil penelitian Bamel, Srinivasan, Saxena, Uprety, \& Neelam (2007), perlakuan benih direndam dengan Asam sulfat selama 20 dan 50 menit menghasilkan daya berkecambah terbaik bagi beberapa jenis Acacia. Selain itu keberhasilan penggunaan asam sulfat ini telah dibuktikan hasil penelitian pada jenis Acacia auriculiformis dengan persentase percambahan bisa mencapai 92-96\% (Olatunji, Maku, \& Odumefun, 2013). Perlakuan perendaman dengan $\mathrm{H} 2 \mathrm{SO} 4$ selama 5-10 menit memiliki persentase perkecambahan tertinggi (92-96\%). begitu pula jenis $A$. Tortilis, $A$. erioloba, dan $A$. nigrescens menyarankan untuk dapat menggunakan asam sulfat pekat dan air panas untuk perlakuan pendahuluannya untuk meningkatkan perkecambahannya (Rasebeka, Mathowa \& Mojeremane, 2013), sedangkan untuk jenis sengon, benih yang dicelupkan ke dalam air panas $60^{\circ} \mathrm{C}$ selama 4 menit dilanjutkan dengan perendaman air dingin selama 12 jam dapat menghasilkan persentase perkecambahan mencapai 100\% (Marthen, Kaya, \& Rehatta, 2013). Oleh karena itu, untuk meningkatkan daya berkecambah biji pilang diperlukan perlakuan pendahuluan yang lebih tepat.

Penelitian ini bertujuan untuk mendapatkan teknik peningkatan daya berkecambah dan kecepatan berkecambah benih pilang.

\section{METODOLOGI}

\section{A. Lokasi dan Waktu Penelitian}

Benih pilang berasal dari Taman Nasional Bali Barat (TNBB). Secara geografis terletak antara $8^{\circ} 05^{\prime} 20^{\prime \prime}$ sampai dengan $8^{\circ} 15^{\prime} 25^{\prime \prime} \mathrm{LS}$ dan $114^{\circ} 25^{\prime} 00^{\prime \prime}$ sampai dengan $114^{\circ} 56^{\prime} 30^{\prime \prime}$ BT. Topografi kawasan terdiri dari dataran landai (sebagian besar datar), agak curam, dengan ketinggian tempat antara 0 sampai dengan 1.414 mdpl. TNBB sebagian besar terdiri dari Latosol. Berdasarkan Schmidt dan Ferguson, kawasan TNBB termasuk tipe klasifikasi D, E, C dengan curah hujan rata-rata D: $1.064 \mathrm{~mm} /$ tahun, E: 972 $\mathrm{mm} /$ tahun, dan C: $1.559 \mathrm{~mm} /$ tahun. Temperatur udara rata-rata $33^{\circ} \mathrm{C}$ pada beberapa lokasi, kelembaban udara di dalam hutan sekitar $86 \%$. Penelitian dilaksanakan di laboratorium Balai Penelitain Teknologi Perbenihan Tanaman Hutan pada tahun 2012.

\section{B. Bahan dan Peralatan}

Bahan yang digunakan adalah jenis pilang $(A$. leucophloea) dengan media perkecambahan pasir dan tanah $(1: 1)(\mathrm{v} / \mathrm{v}))$ dan kertas merang. Peralatan yang digunakan meliputi bak kecambah, germinator, petridish, label, plastik, dan lain-lain.

\section{Prosedur Penelitian}

Pengumpulan buah dengan mengunduh benih yang sudah masak fisiologis yang ditandai dengan kulit buah berwarna hijau kecolatan dan buah yang sudah jatuh dengan sendirinya (Suita. 2010). Kemudian diekstraksi dengan cara benih di jemur sampai benih merekah, kemudian benih dipisahkan dari kulit buahnya secara manual. Untuk membersihkan benih dari kulit ari benih yang menempel dilakukan penjemuran kemudian digosok sehingga kulit ari benih yang menempel terlepas, kemudian baru benih diperlakukan:

\section{Pengujian kadar air benih}

Kadar air dinyatakan dalam persen berat dan dihitung dalam 1 desimal terdekat (ISTA, 2010) dengan rumus sebagai berikut :

$$
\text { Kadar air }=\frac{(\mathrm{M} 2-\mathrm{M} 3)}{(\mathrm{M} 2-\mathrm{M} 1)} \times 100 \%
$$

dimana: M1: berat wadah dan penutup dalam gram, M2: berat wadah, penutup, dan 
benih sebelum pengeringan, M3:berat wadah, penutup, dan benih sesudah pengeringan. Peng-ujian kadar air menggunakan 3 ulangan@5 gram benih.

\section{Kemurnian benih}

Tahapan pengujian, meliputi: pemilihan benih contoh sebanyak 2.500 butir, pemilahan contoh benih ke dalam 3 kelompok (benih murni, benih lain dan kotoran), dan penimbangan berat masing kelompok contoh. Perhitungan persen berat dari masing-masing kelompok menggunakan rumus sebagai berikut :

Benih Murni $=\frac{\mathrm{K} 1}{\mathrm{~K} 1+\mathrm{K} 2+\mathrm{K} 3} \times 100 \%$

Benih lain $=\frac{\mathrm{K} 2}{\mathrm{~K} 1+\mathrm{K} 2+\mathrm{K} 3} \times 100 \%$ $\mathrm{K} 1+\mathrm{K} 2+\mathrm{K} 3$

Kotoran

$$
=\frac{\mathrm{K} 1}{\mathrm{~K} 1+\mathrm{K} 2+\mathrm{K} 3} \times 100 \%
$$

dimana: $\mathrm{K} 1$ = benih murni; $\mathrm{K} 2$ = benih lain; dan $\mathrm{K} 3=$ kotoran

Selisih antara berat contoh dengan berat benih keseluruhan setelah dipisahkan tidak boleh lebih dari 5\%

\section{Penentuan berat 1.000 butir benih}

Dari hasil uji kemurnian, dihitung secara acak 100 butir benih masing-masing sebagai satuan percobaan dengan ulangan 8 kali dan setiap satuan satuan percobaan ditimbang beratnya (dalam gram). Keragaman $\left(\mathrm{S}^{2}\right)$, dan koefisien keragaman dari berat (CV) dihitung dengan rumusan sebagai berikut (ISTA, 2006) :

$\mathrm{S}^{2}=\frac{\mathrm{n}\left(\sum \mathrm{X}^{2}\right)-(\mathrm{X})^{2}}{\mathrm{n}(\mathrm{n}-1)} ; \mathrm{CV}=\frac{\mathrm{S}}{\mathrm{X}} \times 100$

dimana: $\mathrm{x}$ : berat setiap ulangan dalam gram; $\mathrm{n}$ : jumlah ulangan

\section{Metode uji perkecambahan}

Pengujian perkecambahan meliputi pengujian di laboratorium dan pengujian di rumah kaca. Untuk pengujian ini digunakan Rancangan Faktorial dan Rancangan Acak Lengkap. Faktor perlakuan pendahuluan terdiri atas 7 taraf dan faktor media perkecambahan terdiri atas 5 taraf.
$\mathrm{A}=$ Faktor perlakuan pendahuluan

A1 : Kontrol (tanpa perlakuan)

A2 : Benih direndam dalam air kelapa selama 30 menit

A3 : Benih direndam dalam air kelapa selama 60 menit

A4 : Benih direndam dengan $\mathrm{H}_{2} \mathrm{SO}_{4}$ selama 20 menit

A5 : Benih direndam dengan $\mathrm{H}_{2} \mathrm{SO}_{4}$ selama 40 menit

A6 : Benih direndam dalam air panas (suhu $1.000^{\circ} \mathrm{C}$ ) selama 10 detik kemudian masukkan air dingin selama 24 jam

A7 : Benih direndam dalam air panas (suhu $1.000^{\circ} \mathrm{C}$ ) selama 20 detik kemudian masukkan air dingin selama 24 jam

$\mathrm{B}=$ Faktor metoda uji perkecambahan

B1 : UDK (Uji di atas kertas)

B2 : UAK(Uji Antar Kertas)

B3 : UKDdp (Uji Kertas Digulung dengan posisi didirikan)

B4 : Media pasir tanah $(1: 1)$

B5 : Media pasir tanah (1:1) ditutup plastik selama 1 minggu pertama

Ulangan dilakukan sebanyak 4 kali dan masing-masing ulangan terdiri dari 100 butir benih. Respon yang diamati adalah daya berkecambah dan kecepatan berkecambah.

Daya berkecambah ditentukan dengan jumlah benih yang sudah berkecambah normal. Menurut Sadjad (1999), daya berkecambah menjabarkan parameter viabilitas potensial dan rumus daya berkecambah (DB) adalah :

$\mathrm{DB}=\frac{\sum \mathrm{KN}}{\mathrm{N}} \times 100 \%$

$\sum \mathrm{KN}$ : jumlah benih yang menjadi kecambah normal sampai hari ke-60

$\mathrm{N}$ : jumlah benih yang ditabur

Kecepatan berkecambah yang dihitung adalah benih yang berkecambah dari hari pengamatan ke-1 sampai dengan hari terakhir. Dengan penghitungan kecambah normal pada setiap pengamatan dibagi dengan etmal ( 1 etmal = 24 jam $)$. Menurut Sadjad (1999) dan Widajati (2013), kecepatan berkecambah menjabarkan parameter vigor dan rumus kecepatan berkecambah sebagai berikut:

$\mathrm{i}=\mathrm{n}$

$\mathrm{Kct}=\sum_{\mathrm{i}=0} \% \mathrm{Kn} /$ etmal

dimana Kn : Kecambah normal, i : hari pengamatan, dan etmal $=24 \mathrm{jam}$ 


\section{Analisis Data}

Data dianalisis keragamannya dengan uji $\mathrm{F}$ dan jika terjadi pengaruh yang nyata terhadap respon yang diamati, maka dilakukan uji jarak Duncan (Steel and Torrie, 1980).

\section{HASIL DAN PEMBAHASAN}

\section{A. Hasil}

\section{Kadar Air, kemurnian dan berat $\mathbf{1 . 0 0 0}$ butir benih pilang}

Dari hasil pengujian, Pilang mempunyai kadar air yang cukup rendah $(7,04 \%)$. Secara fisiologis benih terbagi dalam 2 kategori yaitu benih ortodok yang toleran terhadap penurunan kadar air (kurang dari 10\%) dan viabilitasnya dapat dipertahankan selama penyimpanan pada suhu rendah; dan benih rekalsitran yang tidak tahan terhadap pengeringan (kadar air awal benih $20-50 \%$ ) yang tidak dapat disimpan pada suhu rendah, sehingga tidak mampu disimpan lama (Bonner, et.al. 1994). Dengan demikian benih pilang dapat dikategorikan benih ortodok.

Kemurnian mencerminkan seberapa bersih kondisi benih lokasi pengumpulan benih. Kemurnian benih pada lokasi pengumpulan benih menunjukkan proporsi benih murni suatu jenis dan banyaknya kotoran dan benih lain yang terkandung di dalamnya ISTA (2010). Benih pilang dari hasil pengujian mempunyai kemurnian yang cukup tinggi yaitu $(99,31 \%)$.

Penentuan berat 1.000 butir benih digunakan untuk memprediksi jumlah benih dalam $1 \mathrm{~kg}$ yang sangat berguna dalam perencanaan penanaman terutama dalam penentuan jumlah benih yang diperlukan untuk persemaian guna memenuhi target bibit siap tanam. Berdasarkan hasil perhitungan diperoleh nilai rata-rata berat 1000 butir benih pilang (23,07 gram), atau berat per 1 $\mathrm{kg}$ benih pilang (43.346 butir).

\section{Perlakuan pendahuluan dan metode uji perkecambahan \\ Hasil analisis ragam menunjukkan bahwa ada pengaruh yang nyata dari metode uji terhadap da- ya berkecambah, perlakuan pendahuluan terha- dap daya berkecambah, dan kecepatan berkecam- bah benih dan interaksi metode uji dengan per- lakuan pendahuluan terhadap daya berkecambah, dan kecepatan berkecambah benih (Tabel 1).}

Tabel(Table) 1. Hasil analisis ragam pengaruh faktor metode uji, perlakuan pendahuluan dan interaksinya terhadap daya berkecambah dan kecepatan berkecambah di laboratorium (Analysis variety results the effect of pre-treatments and germination method to germination percentage and speed of germination)

\begin{tabular}{llcc}
\hline & \multicolumn{1}{c}{$\begin{array}{c}\text { Sumber variasi } \\
\text { No. }\end{array}$} & \multicolumn{2}{c}{ Tingkat signifikan untuk parameter } \\
\cline { 3 - 4 } & \multicolumn{1}{c}{$\begin{array}{c}\text { Daya berkecambah } \\
\text { (Germination percentage) }\end{array}$} & $\begin{array}{c}\text { Kecepatan berkecambah } \\
\text { (Speed of germination) }\end{array}$ \\
\hline 1. & Metode uji (Test method) & $* *$ & tn \\
2. & pendahuluan (Pre-treatments) & $* *$ & $* *$ \\
3. & Metode uji x perlakuan & $* *$ & $* *$ \\
& pendahuluan (Test method x pre- & & \\
& treatments)
\end{tabular}
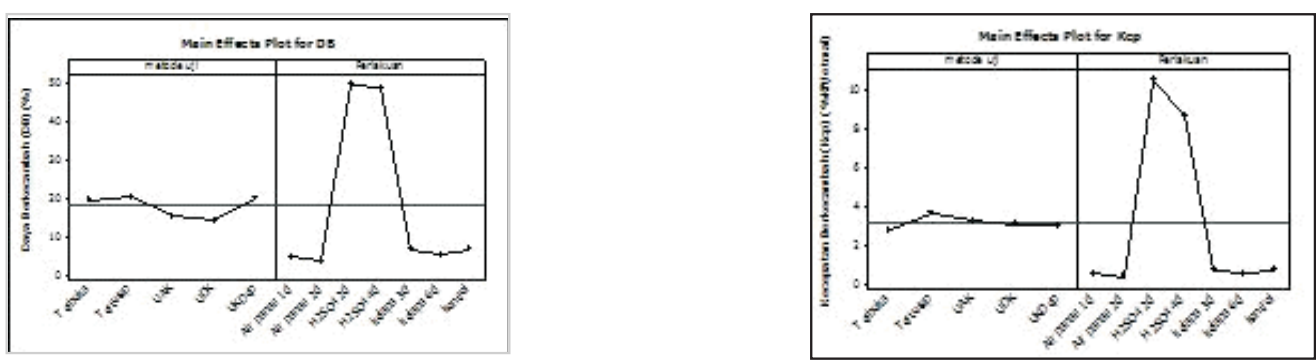

Gambar(Figure) 1. Pengaruh faktor utama terhadap kadar air, daya berkecambah dan kecepatan berkecambah (The main factors influence on water content, germination and speed of germination) 
Gambar 1 memperlihatkan bahwa metode uji dan perlakuan pendahuluan memiliki pengaruh terhadap daya berkecambah dan kecepatan berkecambah benih pilang. Faktor metode uji mempunyai pengaruh pada daya berkecambah dengan metode uji benih dikecambahkan pada bak kecambah terbuka, tertutup dan metode UKDdp, sedangkan untuk kecepatan berkecambah hanya bagus pada bak kecambah tertutup. Faktor perlakuan pendahuluan yang berpengaruh pada daya berkecambah dan kecepatan berkecambah adalah perlakuan benih direndam dengan $\mathrm{H}_{2} \mathrm{SO}_{4}$ selama 20 dan 40 menit.
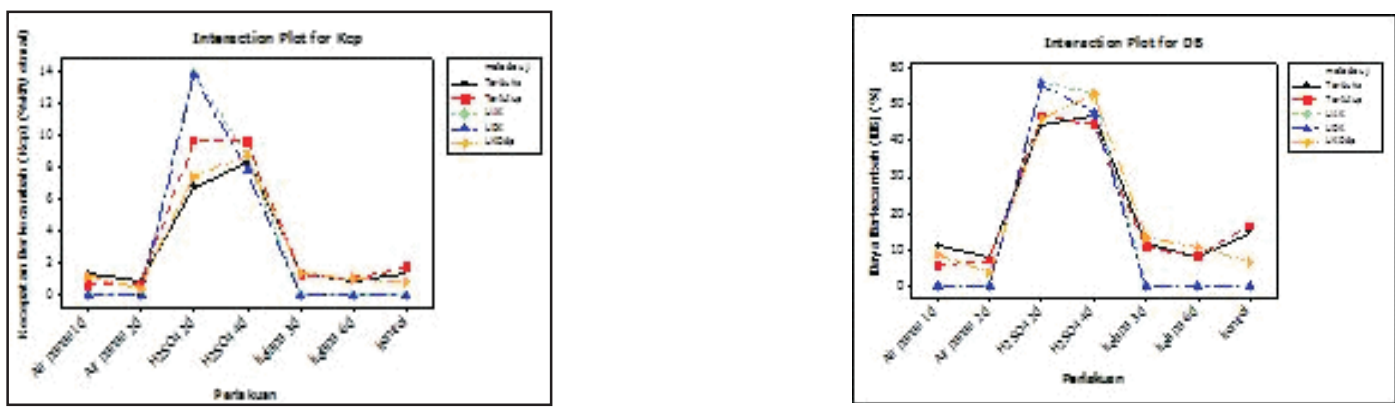

Gambar (Figure) 2. Pengaruh interaksi antar faktor utama terhadap daya berkecambah dan kecepatan berkecambah (The influence of the interaction between the main factors to germination and speed of germination)

Tabel(Table) 2. Hasil analisis ragam dan uji lanjut Tukey pengaruh metode uji dan perlakuan pendahuluan terhadap daya berkecambah dan kecepatan berkecambah (Result of Anova and Tukey significance of test menthods and preliminairy treatment to \% -valibility and speed of viability)

\begin{tabular}{|c|c|c|c|}
\hline No. & Sumber & Daya kecambah & $\begin{array}{c}\text { Kecepatan } \\
\text { berkecambah }\end{array}$ \\
\hline 1 & 2 & 3 & 4 \\
\hline \multirow[t]{6}{*}{1.} & $\begin{array}{l}\text { Faktor metode uji dengan perlakuan benih rendam air } \\
\text { panas selama } 10 \text { detik }\end{array}$ & $* *$ & $* *$ \\
\hline & Bak terbuka - Air panas 10 detik & $11,00 \mathrm{a}$ & $1,28 \mathrm{a}$ \\
\hline & Bak tertutup - Air panas 10 detik & $5,50 \mathrm{ab}$ & $0,65 \mathrm{ab}$ \\
\hline & UAK - Air panas 10 detik & $0 \mathrm{c}$ & $0 \mathrm{c}$ \\
\hline & UDK - Air panas 10 detik & $0 \mathrm{c}$ & $0 \mathrm{c}$ \\
\hline & UKDdp - Air panas 10 detik & $8,75 \mathrm{a}$ & $1,17 \mathrm{a}$ \\
\hline \multirow[t]{6}{*}{2} & $\begin{array}{l}\text { Faktor metode uji dengan perlakuan benih rendam air } \\
\text { panas selama } 20 \text { detik }\end{array}$ & $* *$ & $* *$ \\
\hline & Bak terbuka - Air panas 20 detik & $8 \mathrm{a}$ & $0,86 \mathrm{a}$ \\
\hline & Bak tertutup - Air panas 20 detik & $7,25 \mathrm{a}$ & $0,68 \mathrm{a}$ \\
\hline & UAK - Air panas 20 detik & $0 \mathrm{c}$ & $0 \mathrm{c}$ \\
\hline & UDK - Air panas 20 detik & $0 \mathrm{c}$ & $0 \mathrm{c}$ \\
\hline & UKDdp - Air panas 20 detik & $3,75 \mathrm{ab}$ & $0,42 \mathrm{ab}$ \\
\hline \multirow[t]{5}{*}{3} & $\begin{array}{l}\text { Faktor metode uji dengan perlakuan benih rendam } \\
\mathrm{H}_{2} \mathrm{SO}_{4} 20 \text { menit }\end{array}$ & $* *$ & $* *$ \\
\hline & Bak terbuka $-\mathrm{H}_{2} \mathrm{SO}_{4} 20$ menit & $44,00 \mathrm{ab}$ & $6,74 \mathrm{bc}$ \\
\hline & Bak tertutup $-\mathrm{H}_{2} \mathrm{SO}_{4} 20$ menit & $46,75 \mathrm{ab}$ & $9,70 \mathrm{~b}$ \\
\hline & UAK - $\mathrm{H}_{2} \mathrm{SO}_{4} 20$ menit & $55,75 \mathrm{a}$ & $13,94 \mathrm{a}$ \\
\hline & UDK - $\mathrm{H}_{2} \mathrm{SO}_{4} 20$ menit & $55,0 \mathrm{a}$ & $13,75 \mathrm{a}$ \\
\hline
\end{tabular}


Lanjutan (Continued)

\begin{tabular}{|c|c|c|c|}
\hline No. & Sumber & Daya kecambah & $\begin{array}{c}\text { Kecepatan } \\
\text { berkecambah }\end{array}$ \\
\hline 1 & 2 & 3 & 4 \\
\hline \multirow[t]{6}{*}{4} & UKDdp - $\mathrm{H}_{2} \mathrm{SO}_{4} 20$ menit & $45,75 \mathrm{ab}$ & $7,42 \mathrm{bc}$ \\
\hline & $\begin{array}{l}\text { Faktor metode uji dengan perlakuan benih rendam } \\
\mathrm{H}_{2} \mathrm{SO}_{4} 40 \text { menit }\end{array}$ & $* *$ & $* *$ \\
\hline & Bak terbuka $-\mathrm{H}_{2} \mathrm{SO}_{4} 40$ menit & $46,75 \mathrm{ab}$ & $8,37 \mathrm{ab}$ \\
\hline & Bak tertutup - $\mathrm{H}_{2} \mathrm{SO}_{4} 40$ menit & $44,25 \mathrm{ab}$ & $9,62 \mathrm{a}$ \\
\hline & UAK - $\mathrm{H}_{2} \mathrm{SO}_{4} 40$ menit & $52,75 \mathrm{a}$ & $8,79 \mathrm{ab}$ \\
\hline & UDK - $\mathrm{H}_{2} \mathrm{SO}_{4} 40$ menit & $47,25 \mathrm{ab}$ & $7,88 \mathrm{ab}$ \\
\hline \multirow[t]{6}{*}{5} & UKDdp - H2SO4 40 menit & $52,5 \mathrm{a}$ & $8,75 \mathrm{ab}$ \\
\hline & $\begin{array}{l}\text { Faktor metode uji dengan perlakuan benih rendam air } \\
\text { kelapa } 30 \text { menit }\end{array}$ & $* *$ & ** \\
\hline & Bak terbuka - air kelapa 30 menit & $12,25 \mathrm{a}$ & $1,31 \mathrm{a}$ \\
\hline & Bak tertutup - air kelapa 30 menit & $10,67 \mathrm{a}$ & $1,29 \mathrm{a}$ \\
\hline & UAK - air kelapa 30 menit & $0 \mathrm{~b}$ & $0 \mathrm{~b}$ \\
\hline & UDK - air kelapa 30 menit & $0 \mathrm{~b}$ & $0 \mathrm{~b}$ \\
\hline \multirow[t]{6}{*}{6} & UKDdp - air kelapa 30 menit & $13,25 \mathrm{a}$ & $1,39 \mathrm{a}$ \\
\hline & $\begin{array}{l}\text { Faktor metode uji dengan perlakuan benih rendam air } \\
\text { kelapa } 60 \text { menit }\end{array}$ & $* *$ & $* *$ \\
\hline & Bak terbuka - air kelapa 60 menit & $7,75 \mathrm{ab}$ & $0,87 \mathrm{ab}$ \\
\hline & Bak tertutup - air kelapa 60 menit & $8,25 \mathrm{ab}$ & $1,04 \mathrm{a}$ \\
\hline & UAK - air kelapa 60 menit & $0 \mathrm{c}$ & $0 \mathrm{c}$ \\
\hline & UDK - air kelapa 60 menit & $0 \mathrm{c}$ & $0 \mathrm{c}$ \\
\hline \multirow[t]{7}{*}{7} & UKDdp - air kelapa 60 menit & $10,75 \mathrm{a}$ & $1.00 \mathrm{a}$ \\
\hline & Faktor metode uji dengan perlakuan benih tanpa & $* *$ & $* *$ \\
\hline & Bak terbuka - tanpa perlakuan (kontrol) & $14,50 \mathrm{ab}$ & $1,43 \mathrm{ab}$ \\
\hline & Bak tertutup - tanpa perlakuan (kontrol) & $16,67 \mathrm{a}$ & $1,79 \mathrm{a}$ \\
\hline & UAK- tanpa perlakuan (kontrol) & $0 \mathrm{~d}$ & $0 \mathrm{~d}$ \\
\hline & UDK - tanpa perlakuan (kontrol) & $0 \mathrm{~d}$ & $0 \mathrm{~d}$ \\
\hline & UKDdp - tanpa perlakuan (kontrol) & $6,5 \mathrm{c}$ & $0,82 \mathrm{bc}$ \\
\hline
\end{tabular}

Tabel 2 menunjukkan bahwa benih yang direndam dengan air panas selama 10 dan 20 detik pada metode uji bak terbuka, bak tertutup dan UKDdp tidak berpengaruh secara signifikan terhadap daya berkecambah dan kecepatan berkecambah tetapi berbeda dengan metode uji UAK dan UDK.

Benih yang direndam dengan $\mathrm{H}_{2} \mathrm{SO}_{4}$ selama 20 menit tidak memberikan perbedaan yang signifikan pada daya berkecambah terhadap semua metode uji tetapi berbeda secara signifikan pada kecepatan berkecambah terhadap metode uji UAK dan UDK dengan UKDdp, bak kecambah terbuka dan tertutup, sedangkan yang direndam $\mathrm{H}_{2} \mathrm{SO}_{4}$ selama 40 menit tidak berbeda secara signifikan pada daya berkecambah dan kecepatan berkecambah terhadap semua metode uji.

Benih yang direndam dengan air kelapa 30 dan 60 menit tidak memberikan pengaruh yang signifikan pada metode bak kecambah terbuka, tertutup dan UKDdp tetapi berbeda dengan metode uji UAK dan UDK, sedangkan untuk kontrol (tanpa perlakuan).

\section{B. Pembahasan}

Perlakuan pendahuluan benih direndam dengan air panas selama 10 detik dan 20 detik serta yang direndam dengan air kelapa selama 30 menit dan 60 menit, belum dapat meningkatkan daya berkecambahnya. Hal ini diduga karena kulit benih belum bisa ditembus air kelapa apa- 
bila direndam selama 30-60 menit dan direndam air panas selama 10-20 detik, sehingga benihbenih masih dormansi. Dari hasil peng-amatan terakhir masih banyak benih-benih yang masih keras. Untuk benih pilang, perlakuan pendahuluan yang dapat mematahkan dormansinya adalah benih direndam dengan $\mathrm{H}_{2} \mathrm{SO}_{4}$ selama 20-40 menit. Dengan demikian benih pilang mempunyai dormansi fisik dimana air tidak masuk karena dihalangi oleh kulit yang keras. Menurut Murniati (2013), benih yang mempunyai dormansi fisik kulit benih (Exogeneous Primary Dormansi) dapat diberi perlakuan dengan skarifikasi mekanik dan kimia.

Hasil penelitian mendukung hasil sebelumnya yang dilakukan oleh Bamel et al. (2007) bahwa perlakuan dengan Asam sulfat yang direndam selama 20-50 menit menghasilkan hasil terbaik pada Acacia sp. Begitu dengan jenis saga pohon yang mempunyai dormansi fisik, dengan direndam $\mathrm{H}_{2} \mathrm{SO}_{4}$ selama 30 menit dapat menghasilkan daya berkecambah 92\% (Yuniarti et al., 2001) dan jenis lamtoro apabila direndam dengan $\mathrm{H}_{2} \mathrm{SO}_{4}$ dapat menghasilkan daya berkecambah $83-94 \%$ (Suita et al., 2013; Sudrajat et al., 2008).

Metode uji yang mempunyai nilai tertinggi terdapat pada metode uji UAK dengan daya berkecambah $54,25 \%$ dan kecepatan berkecambahnya $11,37 \% \mathrm{KN} /$ etmal, tidak berbeda nyata dengan metode uji UDK dengan daya berkecambah $51,13 \%$ dan Kecepatan berkecambah $10,81 \% \mathrm{KN} /$ etmal. Jadi apabila benih pilang sudah hilang sifat dormansinya maka dapat berkecambah dengan baik apabila dikecambahkan dengan metode UDK dan UAK, sedangkan apabila masih dormansi maka dengan metode UDK dan UAK tidak berkecambah.

Interaksi terbaik antara perlakuan pendahuluan dan metode uji adalah perlakuan benih direndam $\mathrm{H}_{2} \mathrm{SO}_{4}$ selama 20 menit dengan metode uji UAK dengan daya berkecambah $55,75 \%$ dan kecepatan berkecambah $13,94 \% \mathrm{KN} /$ etmal, tetapi tidak berbeda nyata dengan metode UDK.

Benih pilang yang diberi perlakuan pendahuluan selain dengan $\mathrm{H}_{2} \mathrm{SO}_{4}$, tidak ada yang berkecambah pada metode uji UDK dan UAK. Tetapi apabila diberi perlakuan $\mathrm{H}_{2} \mathrm{SO}_{4}$ benih dapat berkecambah pada semua metode uji. Dengan demikian benih pilang mempunyai dormansi fisik dimana air tidak masuk karena dihalangi oleh kulit yang keras. Menurut Murniati (2013), benih yang mempunyai dormansi fisik kulit benih (Exogeneous Primary Dormansi) dapat diberi perlakuan dengan skarifikasi mekanik dan kimia.

\section{KESIMPULAN DAN SARAN}

1. Kadar air benih pilang termasuk rendah, yaitu di bawah 10\%, sehingga dapat dimasukkan dalam kategori benih ortodoks.

2. Perlakuan pendahuluan dan metode uji perkecambahan terbaik untuk jenis pilang yaitu benih direndam dengan $\mathrm{H}_{2} \mathrm{SO}_{4}$ selama 20 menit dengan metode Uji Di Atas Kertas (UDK) dan Uji Antar Kertas (UAK).

\section{DAFTAR PUSTAKA}

Ardikusuma, R.I. (1954). Percobaan tanaman dalam Kebun Kayu Asing dari Balai Penyelidikan Kehutanan. Pengumuman Istimewa No. 8, Bogor: Balai Penyelidikan Kehutanan.

Bonner, F.T., Vozzo, J.A., Elam, W.W., \& Land, S.B. (1994). Instructor's manual; Tree seed technology training course. United Stated Departement of Agriculture. New Orleans. Louisiana.

Bamel J.S., Srinivasan, K., Saxena, S., Uprety, M., \& B. Neelam. (2007). Methods for breaking seed dormancy in Acacia species. Indian Journal of Plant Genetic Resources.

Bustomi, S. (2009; 2010). Pengelolaan Hutan tanaman Penghasil Kayu Energi. Rencana Penelitian Integratif 2010-2014. Bogor.

ISTA. (2010). International rules for seed testing: Edition 2010. The International Seed Testing Association. Bassersdorf. Switzerland.

Letourneux,Ch.(1970). Tree planting practices in tropical Asia. FAO-Forestry Development Paper No. 11.

Marthen, E. Kaya, \& H. Rehatta. 2013. Pengaruh perlakuan pencelupan dan perendaman terhadap perkecambahan benih sengon (Paraserianthes falcataria L.). Agrologia. Jurnal Ilmu Budidaya Tanaman Vol 2(1): 10-16.

Murniati, E. (2013). Fisiologi perkecambahan dan dormansi benih (Dasar Ilmu dan Teknologi Benih). Bogor: IPB Press.

Olatunji D., Maku, J.O., \& Odumefun, O.P. (2013). The Effect of Pre-treatments on The Germination and early seedlings growth of Acacia auriculiformis Cunn. Ex. Benth. African Journal of Plant Science Vol 7(8) : 325-330. 
Rasebeka, L., Mathowa, T., \& Mojeremane, W. (2013). Effect of seed pre-sowing treatment on germination of three acacia species indigenous to botswana. International Journal of Plant and Soil Science 3 (1) ; 62-70.

Sadjad S, Muniarti, E., \& Ilyas, S. (1999). Parameter pengujian vigor benih komparatif ke simulatif. Jakarta: PT. Grasindo.

Steel, R.G.D., \& Torrie, J.H. (1980). Principles and procedures of statistic. McGraw-Hill, Inc.

Sudrajat, D.J., Suita, E., Ismiati, E., Kartiana, E.R., \& Abay. (2008). Standarisasi pengujian mutu fisik dan fisiologis benih tanaman hutan jenis kihiyang (Albizia procera) dan sawo kecik (Manilkara kauki). Tidak diterbitkan. Laporan Hasil Penelitian. Bogor: Balai Penelitian Teknologi Perbenihan.

Suita, E. (2010). Sekilas tentang pilang (Acacia Leucophloea Rob Wild.) sebagai tanaman serbaguna. Info Benih Vol 14 (2).

Suita, E., Ismiati, E., \& Putra, P.G. (2010). Metode seleksi dan pendugaan umur simpan benih tanaman hutan penghasil kayu energi jenis weru (Albizia procera Benth) dan Pilang (Acacia leucophloea). Tidak diterbitkan. Laporan Hasil Penelitian. Bogor: Balai Penelitian Teknologi Perbenihan.

Suita, E., Suharti, T., Hidayat, A.R., \& Suherman. (2013). Pengujian mutu fisik, fisiologis dan penyimpanan benih jenis lamtoro (Leucaena leucocephala) dan kilemo (Litsea cubeba). Tidak diterbitkan. Laporan Hasil Penelitian. Bogor: Balai Penelitian Teknologi Perbenihan.

Tampubolon, Agustinus P. (2008). Kajian kebijakan energi biomassa kayu bakar (Study of fuelwood biomass energy policies). Jurnal Analisis Kebijakan Kehutanan Vol. 5 No. 1, April 2008: 29-37.

Widajati, E. (2013). Metode pengujian mutu benih (Dasar ilmu dan teknologi benih). Bogor: IPB Press.

Yuniarti, Y., Syamsuwida, D., Sudrajat, D.J., Zanzibar M., Dharmawati, F.D., Muharam, A., Kartiana, E.R., Ismiati, E., \& Sanusi, M. (2001). Teknik penanganan benih orthodoks (2 Jenis). Tidak diterbitkan. Laporan Penelitian, Balai Teknologi Perbenihan No. 343. Bogor. 